\title{
MARKETING STRATEGIES OF DEVELOPMENT ON THE EXAMPLE OF GREEN TOURISM
}

\author{
Kateryna Malinoshevska', Maryna Korzh²
}

\begin{abstract}
Current economic conditions for the development of business entities are characterized by oversaturation with goods and services, as well as high levels of industrial progress. Tourist services are not an exception and their effectiveness depends primarily on the degree of satisfaction of target customers and the coverage of both individual clients as well as corporate ones by the market. At the same time, advertising has become one of the main elements of a marketing strategy in the tourist services system. But the introduction of innovative advertising measures is now unreasonably ignored by tour operators. Therefore, the most promising latest advertising technologies in the implementation of the international marketing strategy of the tour operators are identified in the research paper. Today, in both global and domestic practices, demand for natural rest and recreation is increasing. It is precisely in line with such demand and peasant traditions of Ukraine, so it is necessary to use this opportunity and develop rural green tourism. Green tourism has many different definitions and interpretations. A significant cohort of domestic and foreign scientists distinguishes it as a separate tourist destination; no less opponents consider it an integral part of the ecological tourism structure. However, even extensive research does not allow one to interpret this phenomenon uniquely and individually. Balancing the rural green tourism market is possible when effective state regulation is in place, the condition and feasibility should be investigated. The subject of research is the theoretical and methodological foundation of competitive advantages of rural green tourism. The purpose of this study is to develop and form factors taking into account the competitive advantages of rural green tourism, identify the main stages and possible marketing strategies of rural tourism entities to enter the international market and explore promising methods of lead generation through innovative advertising technologies. To achieve this purpose, the author uses a dialectical method of scientific knowledge and a number of general and special research methods, interconnected and consistently applied according to the general logic of analysis: theoretical generalization, analysis and synthesis, systemic analysis, statistical analysis, comparison, classification and modeling. Logical methods of analysis that summarize the functioning of rural green tourism; methods of statistical processing taking into account statistical data; method of comparative analysis. Conclusion. As a result of research on the basis of the offered factors influencing development of rural green tourism, the theoretical analysis of competitive advantages was checked. Rural green tourism can provide demographic stability and solve socio-economic problems in rural areas. The development of rural green tourism needs support from the state, the establishment of regulatory measures for employment opportunities for the rural population. Rural green tourism can become an organizational and economic component to solve the problems of rural residents.
\end{abstract}

Key words: international marketing strategy, governance, tourism, rural tourism, green tourism, tourism cluster.

JEL Classification: L12, M11, Q13

\section{Introduction}

Nowadays, the world economic system is experiencing a difficult stage in its development, which is accompanied by the expansion of globalization processes, the intensification of information technologies, on the one hand, and the systemic economic crisis, on the other. These

\footnotetext{
Corresponding author:

1 «Highline Media» Ltd., Ukraine.

E-mail: katya.malinoshevska@inter.ua

${ }^{2}$ Kyiv National University of Trade and Economics, Ukraine.

E-mail: marinavladimirovnakorzh@gmail.com
}

processes are accompanied by the increased interest of developed countries in the high-tech industries, thus primarily enhancing competition between individual national economies, which in turn directly affects the competitiveness of international business entities in this area (Kotler et al., 2008; Mazaraki, Melnyk \& Chaiun, 2000). All this leads 
to the increase of risk of international business processes; their participants use different actions and approaches aimed at increasing their own benefit from joining therein (Kelliher et al., 2018). Therefore, there is a particularly high interest in the development of the system of international marketing (Young Entrepreneur Council, 2011), its tools and the formation of an effective marketing communications strategy (De Pelsmacker, van Tilburg \& Holthof, 2018; Lazarus, 2017), the main focus of which is not only successful organization of sales of products on international markets and the implementation of a one-time profitable business operation, but also ensuring reliable positions in the world economic space and maintenance of these positions (Borys, 2017).

Most of the existing approaches to solving this problem are one-sided and are aimed at activating certain marketing functions, the implementation of which is not always consistent with each other, thus leading to a deviation from the expected results in the organization of business processes at the international level. There are many reasons for this result (it depends on both the participants of the business activity and on the level of economic development and competitiveness of their countries, as well as on the specifics of the industry and the market), but the most significant of them are: unprofessionalism in the field of international marketing (which is associated with the spontaneity of running business processes), shortage of resources and funds, lack of experience in international business (especially for the countries in transition), lack of information.

The problem of developing an international marketing strategy for green tourism services through the introduction of innovative advertising technologies is of particular interest (Hernández, Kirilenko, \& Stepchenkova, 2018; Jang et al., 2013; Pan, 2019; Tolmacheva, 2016; Wu, 2018). The urgency of the chosen topic is that competition in the Ukrainian green tourism market is quite high nowadays, while the potential of standard advertising tools is much lower due to the specifics of the market itself, as well as the so-called "information blindness" of the audience, which is caused by excessive consumption of various advertising appeals by modern consumers. This is a well-known fact, that advertising is an industry that is undergoing a constant transformation, as the evolving scientific and technical progress has a direct impact on marketing, offering more innovative means of promoting goods and services (Babich, 2016; Klevoshin, 2016; Kononov, 2014; Sakhno, 2016). It is important to understand, that the very concept of "innovation" includes the high dynamics of changes, updates and additions. Thus, any advertising tool can be considered innovative only as long as it does not lose its relevance and until it is replaced by the newer technology (Koseoglu, Mehraliyev \& Xiao, 2019). Therefore, the choice of advertising media, the main criterion is their compliance with the requirements and opportunities of today will be discussed in this research paper.

Thus, there is an urgent need nowadays not only for the formation of the international marketing system in the system of green tourism, but also for the mechanism that allows to coordinate efforts in the field of international marketing in order to increase the effectiveness of marketing activities in the system of green tourism in general and each entity of this market separately.

\section{Formation of marketing strategy in the international space}

In order to improve the efficiency of the international marketing system and reduce the risk when entering the international market (in particular, in the field of green tourism services), the short-term forecasts should be as close to the reality as possible, which largely depends on the marketing methodology and forecasting (Bozhuk, 2001; He, He \& Xu, 2018).

Therefore, the formulation of the goals of international marketing at the international level should be as clear and concise as possible; the quantitative expression of marketing objectives will make it easier to control their implementation. However, not all goals can be formulated quantitatively.

Supporting goals can be formulated qualitatively: ensuring survival in the conditions of the severe competition in the international market; support and growth of the company's prestige in the world economic space; support and strengthening the image of the company, etc.

There are specific marketing planning models such as SOSTAC, a planning model that aims at simplifying marketing activities and planning, and contains the following elements (Table 1):

- Situation analysis - company position at the moment;

- Objectives - vector of company development;

- Strategy - strategic means of achieving goal; 
Table 1

Components of the SOSTAC model

\begin{tabular}{|c|c|c|}
\hline \# & Stage & Actions \\
\hline 1 & Situation analysis & $\begin{array}{l}\text { - evaluation of } 5 S \text { factors and other KPIs, as well as assessment of trends and forecasts; } \\
\text { - consumer analysis; } \\
\text { - analysis of the market situation; } \\
\text { - analysis of competitors; } \\
\text { - analysis of internal capabilities and resources. }\end{array}$ \\
\hline 2 & Objectives & $\begin{array}{l}\text { Formation of goals by } 5 S \text { criteria: } \\
\text { - Sell - goals for attracting customers and retaining customers; } \\
\text { - Serve - goals for customer satisfaction } \\
\text { - Sizzle - wow factors; } \\
\text { - Speak - attraction of new clients; } \\
\text { - Save - quantitative efficiency improvement. }\end{array}$ \\
\hline 3 & Strategy & $\begin{array}{l}\text { Formulate a strategy according to the next steps (STOP \& SIT): } \\
\text { - Segments; } \\
\text { - Targets; } \\
\text { - Objectives; } \\
\text { - Positioning OVP; } \\
\text { - Sequence: drew attention, tried, bought; } \\
\text { - Integration: CRM, ERP, Database; } \\
\text { - Targeting. }\end{array}$ \\
\hline 4 & Tactics & $\begin{array}{l}\text { According to the marketing mix } 8 \mathrm{P}: \\
\text { - Product; } \\
\text { - Place; } \\
\text { - Price; } \\
\text { - Promotion; } \\
\text { - Process; } \\
\text { - Physical environment; } \\
\text { - People; } \\
\text { - Productivity; } \\
\text { - Including content plan and contract plan. }\end{array}$ \\
\hline 5 & Action & $\begin{array}{l}\text { Definition: } \\
\text { - responsibilities and structural subdivisions; } \\
\text { - processes and systems; } \\
\text { - internal resources, skills and abilities; } \\
\text { - external contractors. }\end{array}$ \\
\hline 6 & Control & $\begin{array}{l}\text { According to the assessment of compliance with the goals and achieved indicators, we are optimizing: } \\
\text { - 5S and other KPIs, involving web analytics; } \\
\text { - user experience and feedback; } \\
\text { - conversion optimization; } \\
\text { - the frequency of data collection; } \\
\text { - reports on the effectiveness of mechanisms, processes and actions. }\end{array}$ \\
\hline
\end{tabular}

- Tactics - tactical means for implementing the action plan;

- Action - operational management;

- Control - comparing results and planned actions.

So, SOSTAC is a well-structured, relevant action model which is used when it comes to external markets, this model describes all the necessary steps in developing a marketing strategy. It can easily adapt to the respective type of the company's activity and a specific target market, as well as to control the implementation of the goals and coordinate them under the influence of factors of the international marketing environment.

In the process of marketing control not only the deviation of the actual indicators from the plans are revealed, but also the reasons behind this deviation and the ways of their elimination are determined. The indicators characterizing both the results of marketing activities and the level of costs associated with their conduct are controlled, and based on their comparison the effectiveness of the marketing program is determined, which may be scheduled, 
intermediate (calculated on the basis of current indicators), final or actual (on the basis of actual results achieved after the event) (Zhang, Chen \& Li, 2019).

\section{Building an international marketing management system in green tourism institutions}

The foundation for marketing activity is the detailed marketing research, on the basis of which it is necessary to analyse and compare the requirements and conditions of the external environment with their own capabilities of each international business actor, resulting in attractive market prospects for them (Heidari et al., 2014). And only at this stage marketing goals and marketing strategy are being formed, and then a marketing planning system and a comprehensive program of actions is being developed in all directions. The marketing planning process is the starting point for all of the company's activities; therefore, this plan must be consistent with other functions of business activity and is part of the green tourism establishment planning system (Figure 1).

The proposed overall system for managing international marketing of green tourism institution allows to systematize all marketing actions and implementing them in a complex, given their interdependence and mutual influence. Thus, international marketing in green tourism is a complex mechanism of interaction of internal variables and factors, which must be as flexible and manageable as possible through the comprehensive influence of the constituent parts of the international environment (from the global economic system as a whole and to a specific industry).

In order to ensure the cyclicity of the marketing management at the international level, an assessment of each individual marketing event (advertising measures in particular) and an analysis of the effectiveness of the system as a whole is carried out, being the basis for the development of the relevant measures (Merinero-Rodriquez \& PulidoFernandez, 2016). Determining the effectiveness of marketing activities is important, especially at the stage of decision-making on a specific event. In this case, one of the main issues that are of interest to both theoreticians and practicing marketers is the question (still open) regarding the construction of a model and the development of a methodology for determining the effectiveness of marketing activities both at the planning stage and at the implementation stage.

The marketing program should focus on the development of both general set of directions and each specific event separately, with specific methods and tools adapted to certain conditions that were formed at the moment in the world economic system as a whole and in separate segments of the international market. Figure 2 shows a diagram of the decision-making and holding marketing event.

It is also very important to evaluate communication technologies in terms of their relevance to the industry specifics. Since the IT market is rather heterogeneous, it is necessary to classify advertising technologies according to the characteristics of its actors.

\section{Marketing communication strategy as a direction of international business tourism development}

Marketing communication strategy as a whole, and advertising measures in particular, should be considered as a direction of long-term development of an international business actor and the system of relations with the internal and external environment. In addition, it is determined by the key marketing goals and, in turn, identifies a market niche, allows forming an infrastructure, minimize adaptation to new external conditions and provide internal coordination of actions, which in general determines the acute need for the formation of an effective planning and management system in international marketing in order to mitigate the risk of entering the international market and to achieve the existing goals and implementation of the main strategy. That is why it is necessary to pay much attention, first of all, to the process of developing marketing plans and communication programs in the international marketing system.

In terms of advertising activities, it is appropriate to classify IT companies on service and product companies. The product model of the IT-company assumes that the company creates and develops its products, which are then sold to a large number of consumers without change. According to the service model, the IT-company implements custom-made projects and does not have its own products, and the resulting software can be used by the same company or any other company. The service model is typical for outsourcing companies (Petruk, 2012). 


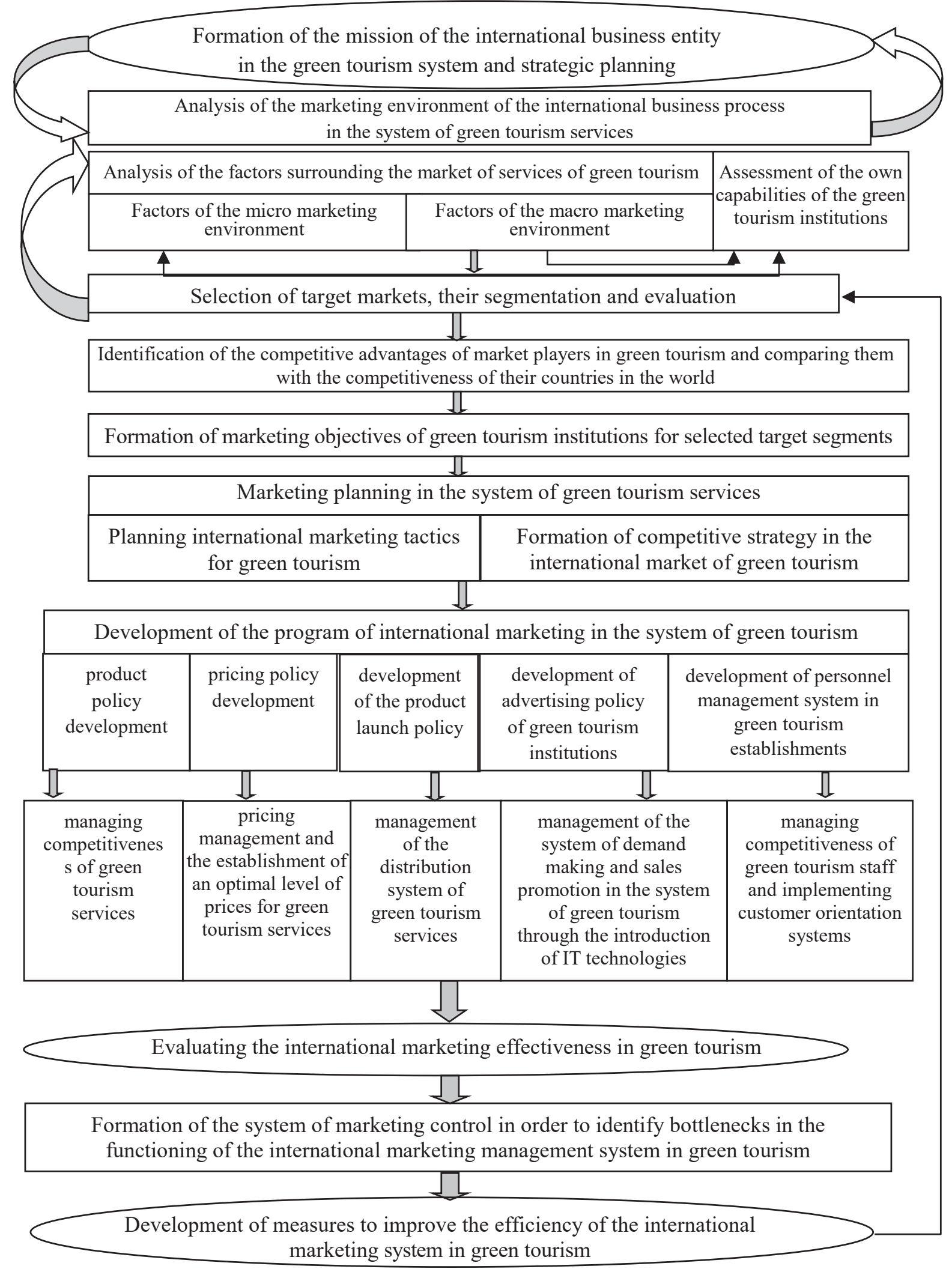

Figure 1. General management system for international marketing in green tourism establishments, taking into account peculiarities of consumers of green tourism services 


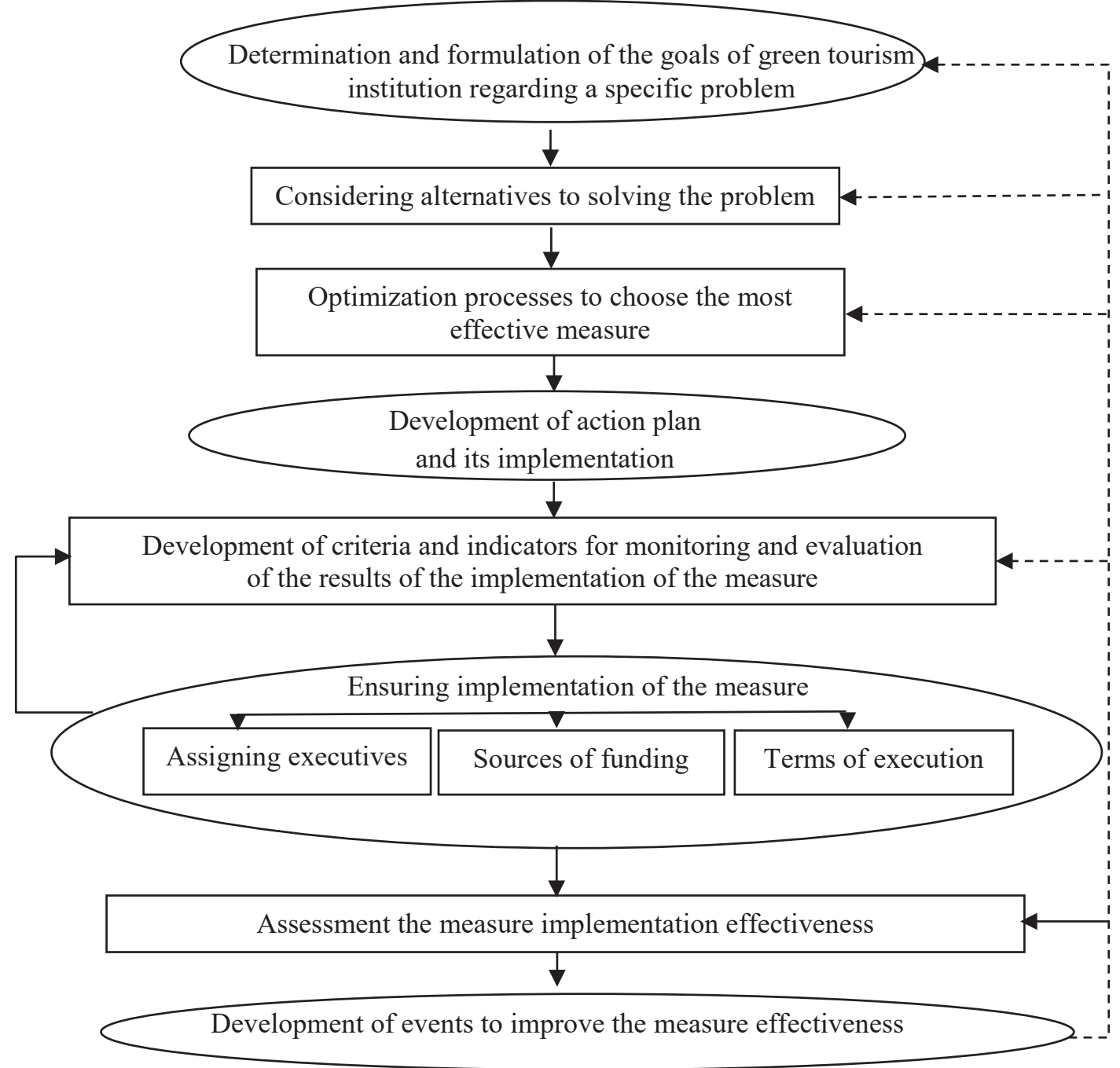

Figure 2. Diagram of decision-making and holding of marketing event in the general program of international marketing of the green tourism

Thus, IT companies are mainly engaged in the development of products for the end user - software for personal use, website creation and management services, various mobile applications and games for different platforms. While service outsourcing firms offer services on the B2B marketplace a variety of software solutions for data management, CRM systems, management and automation of production, and others.

The level of advertising innovation can be determined by the following criteria:

- using professional technical support;

- using latest computer technologies;

- using non-conventional ways to provide information that manifests itself in the emergence of innovative advertising forms (Hlushkova, 2013).

The content of investment support for the innovative development of green tourism establishments is the investment support for different innovative assets in different forms, which gives rise to the ever-increasing production of innovative tourism products of green tourism, the greater the increase in the production of innovative products of green tourism per unit of investment in innovative assets, the higher the effective investment development of green tourism establishments (Figure 3).

It is customary to distinguish external and internal factors that determine the development of various forms of green tourism. External factors include: pricing, the level of tax burden, the conditions for granting loans for the development of green tourism establishments, the level of income of the population (Figure 4).

Internal factors include: natural, logistical, level of development of scientific research, economic, 


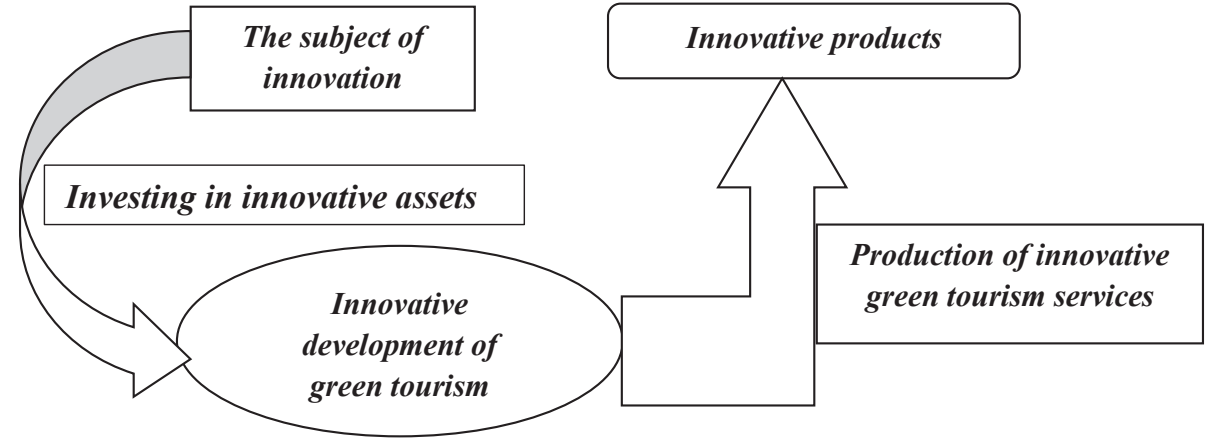

Figure 3. Scheme of innovative development of green tourism entities
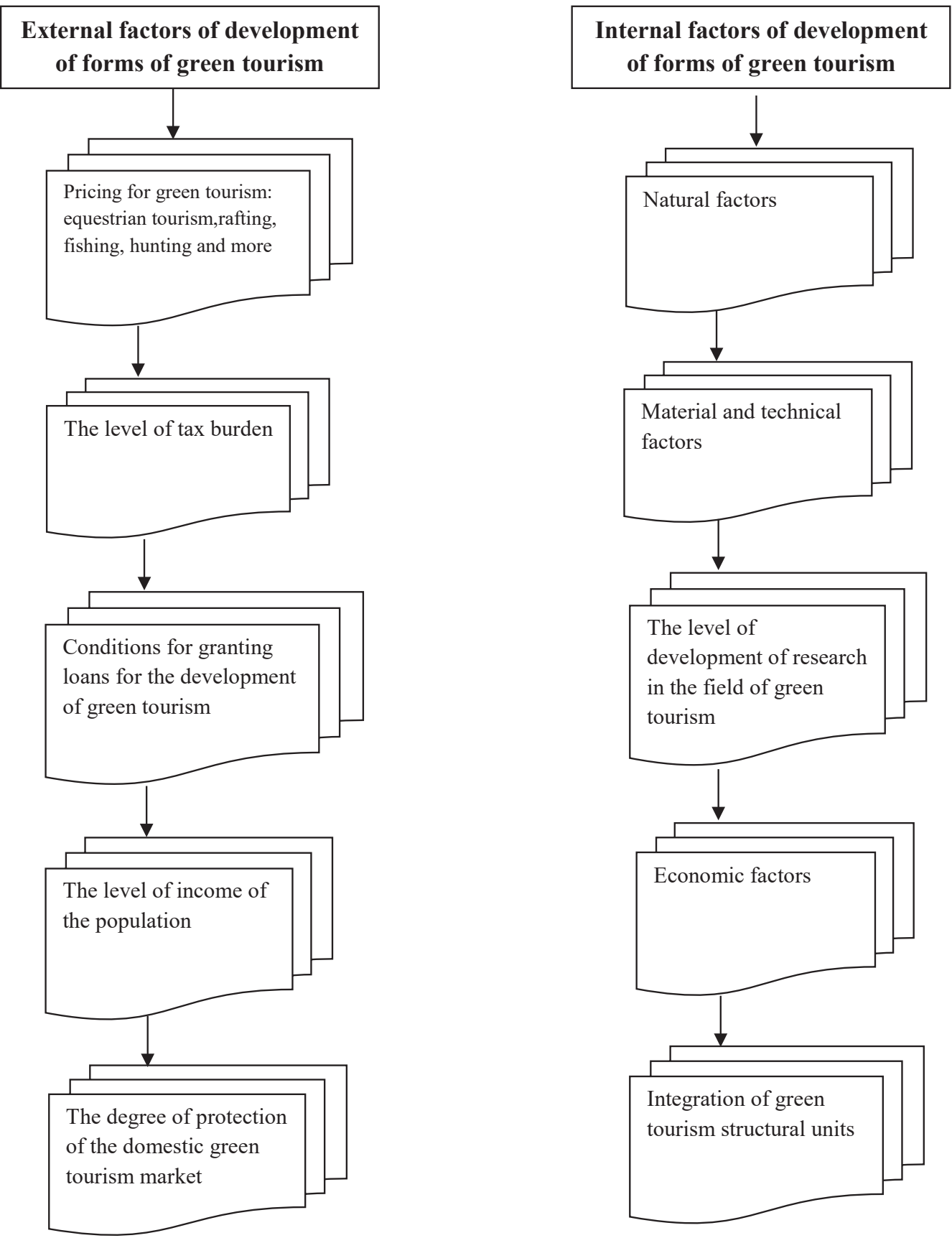

Figure 4. External and internal factors of development of forms of green tourism 


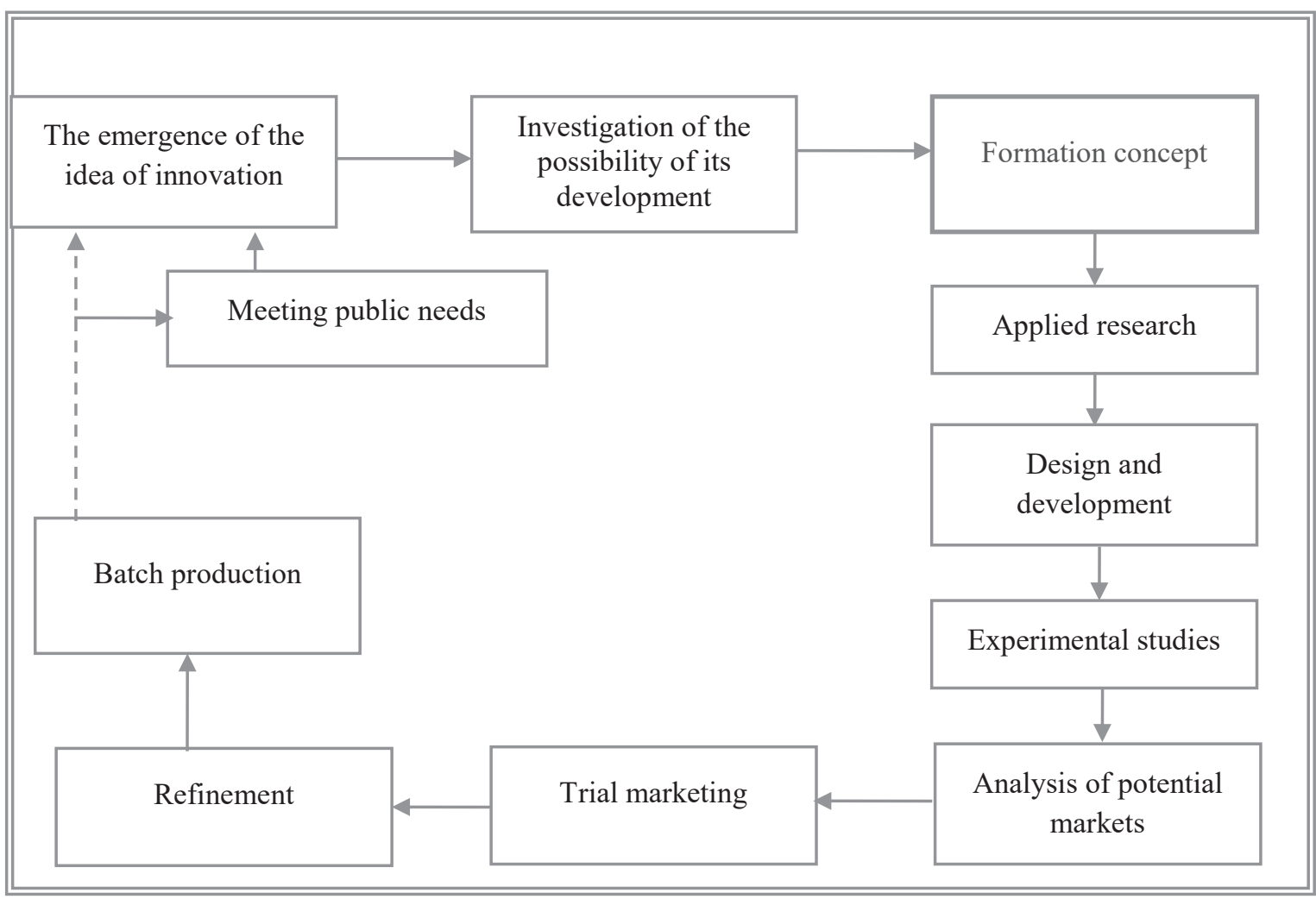

Figure 5. Stages of the innovation process in green tourism establishments

including financial, organizational and managerial, as well as the integration of structural links of green tourism.

It is common to organize innovative activities and select appropriate development strategies to ensure favorable conditions for the economic development of green tourism establishments. Developing a common approach to innovation prospects is important because in the context of globalization there is a unification of economic development trends (Figure 5).

Green tourism, both for holidaymakers and owners - peasants, rural communities, regions and the state as a whole, contributes to the development of many related industries (Biddulph, 2015; Ma et al., 2019; Randelli, \& Martellozzo, 2019; Razzaq et al., 2013; Stylidis et al., 2014). The development of rural green tourism encourages the improvement of rural estates, streets, and villages as a whole, and encourages the development of social infrastructure (Dickinson, \& Robbins, 2008; McAreavey \& McDonagh, 2011).

Consequently, in order to provide a stable passive flow of potential customers, it is necessary to build marketing processes focused on the target market: this is optimization of the company's website in line with current trends, the creation of targeted content, cooperation with local opinion leaders, active management of social media, participation in conferences as speakers, marketing campaigns with landing pages and contextual advertising.

\section{Conclusion}

Based on the analysis of the nature of international marketing, as well as on the basis of modelling of the overall management system of its mechanism, it was concluded that the plan of international marketing is the basis of the activities of green tourism institutions in the field of ensuring the profitability of their operation in the international business, the international marketing system cannot be isolated from planning other functions of economic activity in international business, especially in the field of marketing communications and their advertising component.

As for the advertising green tourism institutions through using modern information technologies, the feasibility of introducing innovative means of advertising for this purpose were determined. The result of the study of this issue was the conclusion about the promising use of IT technologies such 
as smart billboards, the production of souvenir products using sensory and tactile tissue. On the other hand, when selecting the latest advertising tools for a particular company, the need to focus on specific characteristics of the company (budget, target audience, product, etc.) was emphasized.

As a result of the research, it can be concluded that in the context of the current concept of holistic marketing, advertising activity is one of the key elements of the marketing international strategy of the green tourism institutions. It is a complex concept characterized by such features as non-personal nature, the complexity in determining the effect and getting the feedback of the audience, public nature, awareness and ability to convince.

\section{References:}

Babich, Yu. (2016). What is iBeacon and what it eats? MMR. Available at: http://mmr.ua/show/chto takoe_ibeacon_i_s_chem_ego_edyat\#812281065.1487763723 (accessed 11 May 2020).

Biddulph, R. (2015). Limits to mass tourism's effects in rural peripheries. Annals of Tourism Research, 50(1), 98-112. doi: https://doi.org/10.1016/j.annals.2014.11.011

Borys, T. (2017). The Best Advice for Marketers in 2017: Insights from 11 Experts. Hub Spot. Available at: https://blog.hubspot.com/marketing/best-advice-for-marketers\#sm.00000lb98akiwedh7qb2tzi99eed4 (accessed 13 May 2020).

Bozhuk, S. H. (Ed.) (2001). Marketing Communications: Integrated Approach. Saint Petersburg: Piter.

De Pelsmacker, P., van Tilburg, S., \& Holthof, Ch. (2018). Digital marketing strategies, online reviews and hotel performance. International Journal of Hospitality Management, 72, 47-55. doi: https://doi.org/ 10.1016/j.ijhm.2018.01.003

Dickinson, J. E., \& Robbins, D. (2008). Representations of tourism transport problems in a rural destination. Tourism Management, 29(6), 1110-1121.

He, P., He, Y. \& Xu, F. (2018). Evolutionary analysis of sustainable tourism. Annals of Tourism Research, 69, 76-89. doi: https://doi.org/10.1016/j.annals.2018.02.002

Heidari, M., Najafipour, A., Farzan, S., \& Parvaresh, S. (2014). The fundamental distinctive applications of networks in tourism industry: A useful mechanism for trust. International Journal of Academic Research in Economics and Management Services, 3(2), 263-285.

Hernández, J. M., Kirilenko, A. P., \& Stepchenkova, S. (2018). Network approach to tourist segmentation via user generated content. Annals of Tourism Research, 73, 35-47. https://doi.org/10.1016/ j.annals.2018.09.002/.

Hlushkova, T. V. (2013). Innovation Components of the Modern Advertisement. Current Issues of Mass Communication, 14, 140-143.

Jang, S., Tang, C., Park, K., \& Hsu, L. (2013). The marketing-finance interface: a new direction for tourism and hospitality management. Tourism Economics, 19(5), 1197-1206.

Kelliher, F., Reinl, L., Johnson, T. G., \& Joppe, M. (2018). The role of trust in building rural tourism micro firm network engagement: A multi-case study. Tourism Management, 68, 1-12. doi: https://doi.org/10.1016/j.tourman.2018.02.014

Klevoshin, P. (2016). VR and 360 will Replace Conventional Video Advertisement. SOSTAV. Available at: http://www.sostav.ru/publication/vr-22468.html?utm_source=relap\&utm_medium=display\&utm_ campaign=news_promo (accessed 16 May 2020).

Kononov, N. (2014). Who if not Displair: 5 Technologies of Image Projection without Screen. The Village. Available at: http://www.the-village.ru/village/business/newprof/154497-can-touch-this (accessed 16 May 2020).

Koseoglu, M. A., Mehraliyev, F. \& Xiao, H. (2019). Intellectual connections in tourism studies. Annals of Tourism Research, 79, 102760. doi: https://doi.org/10.1016/j.annals.2019.102760

Kotler, F., Armstrong, G., Wong, V., \& Saunders, J. (2008). Basics of Marketing: $5^{\text {th }}$ European edition. Harlow: Pearson/Prentice Hall.

Lazarus, N. (2017). How to Create a Digital Marketing Strategy for 2016: a 15-Point Checklist. Open Minds. Available at: https://openmindsagency.com/?s=How+to+Create+a+Digital+Marketing+ Strategy+for+2016 (accessed 18 May 2020).

Ma, M., Huang, J., \& Lin, Sh., \& Yang, Sh. (2019). From finance to marketing: Initial public offering ownership overhang and marketing in the hospitality industry. International Journal of Hospitality Management, 76(Part A), 71-82. doi: https://doi.org/10.1016/j.ijhm.2018.03.019

Mazaraki, A. A., Melnyk, T. M., \& Chaiun, T. I. (2000). International Marketing: textbook. Kyiv: KNTEU. 
McAreavey, R., \& McDonagh, J. (2011). Sustainable rural tourism: Lessons for rural development. Sociologia Ruralis, 51(2), 175-194.

Merinero-Rodriquez, R., \& Pulido-Fernandez, J. I. (2016). Analysing relationships in tourism: A review. Tourism Management, 54, 122-135.

Pan, S. (2019). Tourism slogans - Towards a conceptual framework. Tourism Management, 72, 180-191.

Petruk, M. (2012). Product and Service Model of IT Company. Learning Project Management. Available at: http://pmkniga.blogspot.com/2012/02/it.html (accessed 16 May 2020).

Randelli, F. \& Martellozzo, F. (2019). Is rural tourism-induced built-up growth a threat for the sustainability of rural areas? The case study of Tuscany. Land Use Policy, 86, 387-398.

Razzaq, A. R. A., Mohamad, N. H., A. Kader, S. Sh. S., Mustafad, M. Z., Ab. Hadi, M. Y., Hamzah, A., \& Khalifah, Z. (2013). Developing Human Capital for Rural Community Tourism: Using Experiential Learning Approach. Procedia-Social and Behavioral Sciences, 93, 1835-1839. doi: https://doi.org/ $10.1016 /$ j.sbspro.2013.10.126

Sakhno, A. (2016). Programmatic for "Newbies": What Is Programmatic and How it Works. Digital Bee. Available at: http://digitalbee.com/blog/digital-marketing/programmatic-dlya-chaynikov-chto-takoeprogrammatik-i-kak-on-rabotaet/ (accessed 11 May 2020).

Stylidis, D., Biran, A., Sit, J., \& Szivas, E. M. (2014). Residents' support for tourism development: The role of residents' place image and perceived tourism impacts. Tourism Management, 45, 260-274.

Tolmacheva, A. (2016). Machine Intelligence in Advertisement: Advertisement which Determine themselves what a Viewer Needs. VC.ru. Available at: https://vc.ru/p/ai-rowley (accessed 17 May 2020). $\mathrm{Wu}, \mathrm{G}$. (2018). Official websites as a tourism marketing medium: A contrastive analysis from the perspective of appraisal theory. Journal of Destination Marketing \& Management, 10, 164-171. doi: https://doi.org/10.1016/j.jdmm.2018.09.004

Young Entrepreneur Council (2011). A 5 Step Primer for Entering an International Market. Forbes. Available at: https://www.forbes.com/sites/yec/2011/09/22/a-5-step-primer-for-entering-aninternational-market/\#6806d9c550a0 (accessed 18 May 2020).

Zhang, K., Chen, Y., \& Li, Ch. (2019). Discovering the tourists' behaviors and perceptions in a tourism destination by analyzing photos' visual content with a computer deep learning model: The case of Beijing. Tourism Management, 75, 595-608. doi: https://doi.org/10.1016/j.tourman.2019.07.002 